\title{
Inclusion versus Experimentation
}

\author{
BILL DURODIÉ
}

Department of Defence Management and Security Analysis, Cranfield University, Swindon, UK

\begin{abstract}
This short reply to criticism of an original paper demonstrates how the critics themselves reflect the limitations originally pointed to. Public dialogue in science is about form not content. Nervous officials, and sadly a few scientists themselves, feel that they need to be seen to consult on such matters with ordinary people. They are creating a new system of patronage in the process. An army of self-appointed communications experts also go so far as to suggest that this makes for better science. This projects a narrow utilitarian or instrumentalist model whereby science should serve certain pre-determined social goals. This debases science, discrediting its institutions and accentuating the very problem they seek to solve.
\end{abstract}

KEY WORDS: science, society, dialogue, expert, risk, uncertainty, trust, public, values

In the spirit of dialogue, Roland Jackson, Fiona Barbagallo and Helen Haste have written a reply to my essay 'Limitations of Public Dialogue in Science and the Rise of New "Experts", (Durodié 2003). I am grateful for this, not just because their response offers me an opportunity to expand further on these matters, but also because it reflects some of the problems I raised.

Jackson et al. focus their discussion on the 'context, purposes and practice of public dialogue'. This reflects an absence of much discussion as to what the dialogue should actually be about thereby confirming one of my original points. That is, that for the advocates of public dialogue, process is far more important than content. Quantity and access are prioritised over quality and insight. What is most striking however, is how limited their description of the context is. In my original piece I concluded that 'as the aspiration for real social change has receded, so science has been inflated in terms of import and impact, out of all proportion'. This is a vital point. It partly explains why scientific development is now increasingly viewed as a risk.

As Jackson et al. must know, science, as well as transforming society, is itself a product of society. Indeed, the scientific revolution was born in a period of dynamic social change, becoming in its turn a contributor to that change. It derived from a

Correspondence Address: Bill Durodié, DDMSA, Cranfield University, Shrivenham, Swindon SN6 8LA. Email: w.durodie@cranfield.ac.uk 
wider process of social transformation and reflected a faith in humanity itself, rather than merely in science. It is the demise of such aspirations, as well as the actions associated with them, which has encouraged today the advent of an increasingly alienated sense of dependence upon a supposedly deterministic science. This has been bad for society and bad for science too. Science's aims and methods have suffered from the corrupting influence of being tailored to explain, or address, essentially social processes and phenomena.

If it is true, as Jackson et al. suggest, that 'there is a risk of a strong reaction' if research outcomes are found to be 'at odds with the values or expectations' of the public, then presumably clarifying what the public's values truly are should be the primary task. And referring, as they do, to 'publics' rather than the public, simply begs the question as to quite how many publics there are and which of these we should pay attention to. Both these processes are political rather than scientific matters.

Jackson et al. allude several times to the need to locate their proposals within the 'wider political process'. It therefore seems somewhat remiss of them to fail to point to the noticeable demise, both quantitative and qualitative, of broader debate and engagement in worldly affairs over the contemporary period. Aside from the continued poor turnout in the UK general election, politics, as I am sure most would agree, should be about more than mere voting. It requires a debate as to vision and principles, as well as contesting and acquiring the means to realise these. Dialogue in relation to science-related issues, or 'dialogue on', as they would have it, appears a poor substitute for this more ambitious and active, participatory role in shaping social consciousness and society as a whole. It rather seems to reflect the lowering of horizons born of an age when the desire to transform the world through mass political engagement is, in their own words, 'perhaps an ambition too far'. But just as the initial dynamic behind science was social change, so the absence of this circumscribes science too, as well as shaping an exaggerated sense of science's impact upon us.

Ironically, it was always radicals who understood the potential of science to upset vested positions of prejudice and power. Accordingly, science was traditionally championed by the left as a practical battering-ram with which to challenge superstition and diktat. But the left also lost their faith in science, initially through their conflation of it with post-war American militarism, and more recently through their attempts to harness environmental ideals, in order to provide themselves with a sense of purpose, as well as a constituency, in the post-Cold War world order. Accordingly, the suggestion that I 'wish for a past golden age when experts were experts, authorities were automatically respected by tradition and everyone knew their place', is simply baffling. Rather, it is those who would wish to see science instrumentally harnessed to 'address societal needs' in an age when our sense of what is possible, or desirable, has been so diminished, who are the real conservatives.

For those who have given up on the desire for social transformation, believing this to be too ambitious, then maybe teaching scientists 'how to talk' appears a more achievable goal. Sadly, within the context of diminished aspirations that they themselves reflect, shape and drive, this can only serve to further undermine expectations, 
as well as corrupting the individuals, ideals and institutions they purport to be helping. For instance, rather than talking to the public as to the possibility of a link between the MMR triple-vaccine and childhood autism, science and society would have been better served, in the first instance, by a more robust internal debate. It was this failure that propelled the debate into the public sphere, where few were qualified to comment upon, or interpret, the evidence. Instead a cultural mood attuned to constant speculation as to worst-case scenarios determined the direction of much of the discussion, seriously impairing the UK vaccination programme.

This proclivity to assume negative outcomes is encouraged by Jackson et al. when they talk of the need to take into account science's 'inherent uncertainties'. They seem not to envisage the possibility of positive solutions to uncertainty, and this potentially limitless task, of accounting for the unaccountable, fails to highlight that science has always been replete with contradiction. What is new today is a broader crisis of confidence in dealing with uncertainty, and a concomitant absence of direction, that has afflicted both society at large, and science in consequence. This loss of nerve, in the face of what has always been an inevitably uncertain future, has led to a wholesale corruption of the aims, principles and standards of scientific inquiry. It is this debasement, rather than a mere disheartening, that I sought to draw attention to when alluding to 'the demoralization of scientists' in my original essay. It is a wonder that those who prioritise communication over content should have failed to appreciate this distinction.

Another area of confusion arises from their own definition of dialogue. That they should place such store by this word is itself quite telling. Jackson et al. describe dialogue as 'a context', before suggesting that it 'locates scientific developments in a wider social context'. A context within a context then? Given, as indicated above, that their grasp of context itself seems rather limited, this can not bode too well for the analysis that ensues.

Dialogue is variously described as 'an open exchange and sharing', something that 'enables' inclusion and seeks to 'recognise' other factors. As dialogue 'does not remove authority' from science or 'somehow set public opinion as equal', there appears to be no requirement to act upon it, just to 'respect' and 'acknowledge'. Adopting the therapeutic language of our times, dialogue is no longer a means to an end, but rather an end in itself. So much for the possibility of real change then.

In fact, history rather suggests that when the public truly desire to be involved in decision-making then there is little that can hold them back. They certainly do not require to be 'empowered' by those in power, or those with good intentions. Such narrow, goal-oriented support, for 'improving confidence' or 'reducing conflict', constitutes a patronage of a more profound kind than merely being condescending to others, as it appears is the only way in which Jackson et al. understand the term patronise. Ironically, whilst preaching the virtues of humility in science, Jackson et al. confidently tout the input and relevance of social scientists who 'can and should offer valuable specialist expertise'. Notably, this claim to authority is not associated with any calls for public dialogue in the social sciences. This inadvertently accepts the 
input of such experts as having no real and lasting impact upon the world in the way that they believe science does.

Somewhat more ominously they propose that dialogue is somehow necessary to secure science's 'licence to practise'. In this narrowly instrumentalist model of science, 'public consent' replaces royal assent in determining whether, on the basis of providing certain tangibly perceived 'benefits', scientists should be allowed to pursue their inquiries. In fact, science's 'licence to practise' derives from its results. Many of these are not envisaged, nor can they be, when scientists first experiment. To demand otherwise is to confuse open-ended inquiry with a form of methodological prescription better known to social scientists writing funding applications. No doubt Jackson et al. are more familiar, and possibly more comfortable with the latter.

Certainly, they are at ease with projecting their own prejudices onto the public. In their speculative discussion about nanotechnology, a nascent area of science yet to impinge upon popular consciousness in any way, these dialogic communicators quite literally, and unashamedly, speak on behalf of the public. They begin their statements with such phrases as, 'The public is likely to want to see...', and even, 'It will want to ask...'. It seems as though those who speak the loudest of the need for evidence-based uncertainty and humility are amongst the least able to practice it.

Whilst suggesting that the inclusion of non-scientists might lead to 'a broader range of options' being discussed, they also appear blind to the fact that dialogue about 'benefits, concerns and moral issues' can actually narrow the scope of discussion. As the notion that it is possible, even desirable, to shape or lead public opinion, is entirely absent from their description of dialogue, this approach can only mean adapting to the lowest common denominator, or contemporary prejudices and fears.

Consensus and compromise may appeal to woolly-minded bureaucrats in Whitehall and Brussels, but science is poorly served by it. Like it or not, policy-making necessitates a conflict in society between groups with competing aims. Indeed, whether scientific inquiry is best advanced by demanding a dialogue with the public is one of those conflicts. That the champions of inclusion over experimentation should now include the chief executive of the British Association for the Advancement of Science speaks volumes as to the position of some amongst the scientific elite within this debate.

In conclusion, it should be noted that I do not oppose education or public discussion about science, simply the notion that this should inform the direction of science itself. Politicians and officials who promote dialogue in science in order to relate to the public, and scientists who need the prop of relevance and inclusion to justify themselves, impoverish both their fields of activity. They reflect elites who have lost the confidence to get on with what they purport to promote. It is high time they were prised apart.

\section{References}

Durodié, B. (2003) Limitations of public dialogue in science and the rise of new 'experts', Critical Review of International Social and Political Philosophy, 6(4), pp. 82-92. 